\title{
PERBANDINGAN KADAR SATURASI OKSIGEN HARI PERTAMA DAN HARI KETIGA PADA BAYI BARU LAHIR
}

\author{
${ }^{1}$ Adriaan W. Kaunang \\ ${ }^{2}$ Rocky Wilar \\ ${ }^{2}$ Johnny Rompis \\ ${ }^{1}$ Kandidat Skripsi Fakultas Kedokteran Universitas Sam Ratulangi \\ ${ }^{2}$ Bagian Ilmu Kesehatan Anak FK Unsrat - RSUP Prof Dr. R. D. Kandou Manado \\ Email: akaunang11_014@yahoo.com
}

\begin{abstract}
Every cells in human body needs oxygen to implement metabolism function, therefore the process maintenance oxygenation is an effort to determine the needs of supply oxygen to every cells in human body. Oxygen saturation is one of a value that we must consider on determine the needs of supply oxygen in our body especially in newborn because when the oxygen saturation is low will reduce the supply oxygen to cells. The result of paired T-test says that there are significant changes between first day and third day of oxygen saturation in newborn $(\mathrm{p}<0,001)$.
\end{abstract}

Keywords. oxygen saturation, newborn

\begin{abstract}
Abstrak: Setiap sel tubuh manusia membutuhkan oksigen untuk melaksanakan fungsi metabolisme, sehingga mempertahankan oksigenasi adalah upaya untuk memastikan kecukupan pasokan oksigen ke jaringan atau sel. Saturasi oksigen merupakan salah satu hal yang patut kita perhatikan dalam penilaian kecukupan pasokan oksigen pada tubuh kita terutama pada bayi baru lahir karena ketika saturasi oksigen rendah maka mengakibatkan pasokan oksigen ke jaringan berkurang. Hasil uji t berpasangan menyatakan ada perbedaan yang sangat bermakna $(\mathrm{p}<0,001)$.
\end{abstract}

Kata kunci: saturasi oksigen, bayi baru lahir

Setiap sel tubuh manusia membutuhkan oksigen untuk melaksanakan fungsi metabolisme, sehingga oksigen merupakan zat terpenting dalam kehidupan manusia. Mempertahankan oksigenasi adalah upaya untuk memastikan kecukupan pasokan oksigen ke jaringan atau sel. ${ }^{1}$ Kekurangan pasokan oksigen di dalam tubuh dapat menyebabkan kerusakan jaringan pada tubuh diakibatkan karena hipoksia jaringan. ${ }^{1,2}$ Mengetahui apakah pasokan oksigen pada tubuh kita cukup atau tidak adalah hal yang penting untuk diketahui. ${ }^{1,3}$ Pada penilaian kecukupan pasokan oksigen ke jaringan tergantung tiga faktor penting yaitu: kadar hemoglobin, curah jantung, dan oksigenasi. Saturasi oksigen bergantung pada pergerakan udara, pertukaran gas di alveolus, dan aliran darah di paru. ${ }^{5}$ Saturasi oksigen merupakan salah satu hal yang patut kita perhatikan dalam penilaian kecukupan pasokan oksigen pada tubuh kita terutama pada bayi baru lahir karena ketika saturasi oksigen rendah maka mengakibatkan pasokan oksigen ke jaringan berkurang. ${ }^{1,3}$

Saturasi oksigen adalah ukuran seberapa banyak oksigen yang mampu dibawa oleh hemoglobin. ${ }^{3,6}$ Pengukuran kadar saturasi oksigen merupakan hal yang perlu dilakukan agar dapat diketahui apakah terdapat kekurangan oksigen yang mampu dibawa oleh darah ke seluruh tubuh. $^{3-5}$ Kadar saturasi oksigen pada bayi 
baru lahir sangat penting untuk diketahui karena ketika kadar saturasi oksigen pada bayi baru lahir rendah maka patut diwaspadai apakah terdapat kelainan hemodinamika pada bayi tersebut. ${ }^{4,5}$ Pengukuran kadar saturasi oksigen pada bayi baru lahir dapat membantu mendeteksi dini kelainan-kelainan bawaan pada bayi. ${ }^{2-4}$ Terdapat empat kadar saturasi oksigen yang perlu kita ketahui pertama adalah saturasi oksigen arteri $\left(\mathrm{SaO}_{2}\right)$, kedua adalah saturasi oksigen vena $\left(\mathrm{SvO}_{2}\right)$, ketiga adalah saturasi oksigen jaringan $\left(\mathrm{StO}_{2}\right)$, dan yang terakhir adalah saturasi oksigen perifer $\left(\mathrm{SpO}_{2}\right)$. Pengukuran $\mathrm{SpO}_{2}$ dengan memakai Pulse Oxymetry (PO). ${ }^{3-5}$ Nilai normal kadar saturasi oksigen berkisaran 95\% sampai 100\% dan pada bayi baru lahir diatas 88\% masih dianggap normal. ${ }^{4}$

Di Amerika Serikat dilakukan pengamatan kadar saturasi oksigen dari menit pertama sampai menit kesepuluh pada 200 bayi baru lahir dengan usia kehamilan lebih dari 36 minggu. Pada menit pertama kelahiran bayi, $\mathrm{SpO}_{2}$ bernilai $71 \%$ dan setiap satu menit akan bertambah hingga pada menit ke sepuluh menjadi 98\%, ${ }^{4,5,7-9}$ meskipun pada bayi lahir prematur kadar saturasi oksigen sedikit lebih rendah tetapi masih dalam batas sekitar 91\%-97\%, yang artinya masih dalam batas normal. ${ }^{4,10-12}$ Pada bayi lahir pervaginum terdapat perbedaan kadar $\mathrm{SpO}_{2}$ dengan bayi yang lahir seksio sesarea. Bayi lahir pervaginum memiliki $\mathrm{SpO}_{2}$ yang lebih tinggi dibandingkan pada bayi lahir seksio sesarea yaitu $96 \%$ pada bayi lahir pervaginam dan $94 \%$ pada bayi lahir seksio sesarea. $^{7-9}$ Terdapat beberapa penelitian yang mengamati kadar saturasi oksigen menit pertama sampai menit ke sepuluh pada bayi baru lahir, ${ }^{7-12}$ meskipun hasil yang didapat setiap penelitian berbeda tetapi perbedaan kadar saturasi oksigen pada bayi lahir cukup bulan dan lahir prematur tetap berkisar antara dari 91\% hingga 98\% kadar $\mathrm{SpO}_{2}$. Hanya terdapat beberapa perbedaan sedikit pada menit pertama, ketiga, dan kelima nilai saturasi oksigen perifernya. ${ }^{4,5,7-12}$ Nilai saturasi oksigen pada bayi baru lahir ditoleransi dari $88 \%$ sampai $92 \%$ masih dikatakan normal. ${ }^{4,5,9}$

Pada hari ketiga kelahiran, nilai kadar $\mathrm{SpO}_{2}$ yang diukur oleh pulse oxymetry diharapkan sudah mencapai 95\% atau lebih, sebab ketika masih di bawah target ataupun jauh di bawah target maka bayi tersebut harus diobservasi lebih lanjut untuk adanya dugaan mengalami kelainan hemodinamika pada bayi tersebut seperti contoh Penyakit Jantung Bawaan (PJB). ${ }^{4,5,13-15}$ Pada PJB nilai pulse oxymetry berkisar antara 90\%-94\% dengan berbagai pertimbangan manifestasi klinik yang terdapat pada congenital heart defect. ${ }^{4,5,14}$ Pada 6 sampai 36 jam nilai saturasi oksigen bayi tersebut kurang dari 90\% maka segera lakukan ekokardiografi, selain itu ketika nilai saturasi oksigen diantara $90 \%$ sampai 94\% perlu dilakukan observasi pada bayi tersebut, setelah 4 sampai 6 jam nilai saturasi sudah lebih dari 95\% maka keadaan bayi normal tetapi ketika masih di bawah 95\% maka lakukan ekokardiografi dengan segera karena dicurigai terdapat congenital heart defect pada bayi tersebut. $^{14}$

Dengan mengukur kadar saturasi oksigen pada bayi baru lahir kita dapat dengan mudah mendeteksi lebih dini halhal buruk yang mungkin dapat terjadi pada anak dimasa pertumbuhannya, ${ }^{1-5,16-18}$ oleh sebab itu penulis tertarik untuk melakukan penelitian dengan melakukan pengukuran saturasi oksigen untuk membandingkan kadar saturasi oksigen di hari pertama dan hari ke tigapada bayi baru lahir.

Tujuan dari penelitian ini untuk mengetahui gambaran kadar saturasi oksigen di hari pertama dan hari ketiga pada bayi baru lahir.

\section{METODE PENELITIAN}

Penelitian ini dilakukan dengan menggunakan metode penelitian analitik observasional prospektif dengan desain penelitian kohort prospektif. Penelitian dilaksanakan di Sub Bagian Neonatologi Bagian Ilmu Kesehatan Anak FK Unsrat RSUP Prof Dr. R. D. Kandou Manado selama 4 bulan pada bulan Oktober tahun 
2014 sampai bulan Januari tahun 2015. Populasi pada penelitian ini adalah semua bayi baru lahir yang dirawat di instalasi rawat inap di Sub Bagian Neonatologi Bagian Ilmu Kesehatan Anak FK Unsrat RSUP Prof Dr. R. D. Kandou bulan Oktober sampai Desember tahun 2014. Jumlah sampel yang di ambil adalah 133 bayi baru lahir yang memenuhi kriteria inklusi dengan pemilian sampel menggunakan consecutive sampling.

Kriteria inklusi adalah bayi baru lahir kurang bulan, cukup bulan, dan lebih bulan, serta bayi baru lahir dengan cara normal, dengan cara seksio sesarea, dengan cara ekstraksi vacum, dan dengan cara ekstraksi forcep. Kriteria ekslusi adalah bayi baru lahir yang mengalami asfiksia dan yang mengalami kelainan kongenital.

Cara pengambilan data dengan melakukan anamnesis Semua bayi baru lahir mengenai umur kehamilan dari ibunya dengan cara menetukan hari pertama haid terakhir. Setelah itu dilakukan pemeriksaan fisis lengkap. Selanjutnya dilakukan pengukuran berat badan dan tinggi badan. Setelah semua kriteria inklusi sudah didapatkan peneliti mengukur kadar saturasi bayi baru lahir pada hari pertama atau 10 menit sampai 24 jam setelah bayi lahir dan hari ketiga atau lebih dari 48 jam sampai 72 jam setelah bayi lahir dengan menggunakan pulse oxymetry. Setelah pengukuran dilakukan pencatatan hasil yang telah didapatkan. Setelah mendapatkan hasil yang patut diobservasi, lakukan observasi pada hasil tersebut. Hasil yang didapatkan kemudian diolah dan disajikan dalam bentuk tulisan dan tabel distribusi frekuensi.

\section{HASIL PENELITIAN}

Penelitian ini dilakukan mulai bulan Oktober 2014 sampai dengan Januari 2015 pada bayi baru lahir diSub Bagian Neonatologi Bagian Ilmu Kesehatan Anak FK Unsrat - RSUP Prof Dr. R. D. Kandou Manado. Data yang diperoleh disajikan dalam bentuk tabel distribusi.

\section{Karakteristik Subyek penelitian}

Sampel penelitian terdiri_dari 133 bayi baru lahir. Median berat badan lahir 3100 gram dengan berat badan lahir terendah 1600 gram dan berat badan lahir tertinggi 5200 gram. Median panjang badan lahir 48 cm dengan panjang badan lahir terendah 41 $\mathrm{cm}$ dan panjang badan lahir tertinggi $52 \mathrm{~cm}$ (Tabel 1).

Tabel 1. Karakteristik subyek penelitian

\begin{tabular}{lc}
\hline \multicolumn{1}{c}{ Variabel } & $\begin{array}{c}\text { Bayi baru lahir } \\
(\mathrm{n}=133)\end{array}$ \\
\hline Jenis kelamin & \\
$\quad$ Lelaki, n (\%) & $64(48,1)$ \\
$\quad$ Perempuan, n (\%) & $69(51,9)$ \\
Umur kehamilan & \\
$\quad$ Kurang bulan, n (\%) & $15(11,28)$ \\
$\quad$ Cukup bulan, n (\%) & $96(72,18)$ \\
$\quad$ Lebih bulan, n (\%) & $22(16,54)$ \\
$\begin{array}{l}\text { Berat badan lahir, rerata } \\
\text { (SB) gram }\end{array}$ & 3078,72 \\
$\begin{array}{l}\text { Panjang badan lahir, } \\
\text { rerata (SB) cm }\end{array}$ & $(558,152)$ \\
\hline
\end{tabular}

\section{Perbandingan kadar saturasi oksigen hari pertama dan hari ketiga}

Median kadar saturasi oksigen bayi baru lahir pada hari pertama 95\% dengan kadar saturasi oksigen terendah 88\% dan tertinggi 99\%. Median kadar saturasi oksigen bayi baru lahir pada hari ketiga 97\% dengan kadar saturasi oksigen terendah 90\% dan tertinggi 99\% (Tabel 2).

Tabel 2. Perbandingan kadar saturasi oksigen hari pertama dan hari ketiga pada bayi baru lahir.

\begin{tabular}{|l|c|c|c|}
\hline Variabel & $\begin{array}{c}\text { Kadar } \mathrm{SpO}_{2} \\
\text { hari pertama } \\
(\mathrm{n}=133)\end{array}$ & $\begin{array}{c}\text { Kadar } \\
\mathrm{SpO}_{2} \text { hari } \\
\text { ketiga } \\
(\mathrm{n}=133)\end{array}$ & $\begin{array}{c}\text { Nilai } \\
\mathrm{p}^{*}\end{array}$ \\
\hline $\begin{array}{l}\text { Kadar } \\
\text { saturasi } \\
\text { oksigen, } \\
\text { rerata (SB) } \\
\%\end{array}$ & $94,72(2,93)$ & 96,86 & $<0,001$ \\
$(1,7)$ & \\
\hline
\end{tabular}

* Uji-t berpasangan 


\section{BAHASAN}

Dari data perbandingan kadar saturasi oksigen hari pertama dan hari ke tiga pada bayi baru lahir (Tabel 2) menyatakan bahwa nilai rerata kadar saturasi oksigen pada bayi baru lahir terdapat peningkatan dibandingkan dengan hari pertama. Besarnya peningkatan kadar saturasi oksigen pada hari pertama dan hari ketiga adalah 1,9\%. Hasil uji $\mathrm{t}$ berpasangan menyatakan ada perbedaan yang sangat bermakna antara kadar saturasi oksigen hari pertama dan hari ketiga pada bayi baru lahir ( $\mathrm{p}<0,001)$. Hasil penelitian ini sama dengan hasil penelitian pada universitasuniversitas yang berada di luar negeri seperti pada American Academy of Pediatrics, USA yang menyatakan bahwa terdapat perningkatan kadar saturasi oksigen di pemeriksaan ke dua dibandingkan dengan pemeriksaan pertama $^{7}$ dan pada penelitian di universitas California, San Francisco, USA tahun 2010 yang menyatakan bahwa pada hari ketiga kadar saturasi oksigen bayi baru lahir terdapat peningkatan dibandingkan dengan hari pertama atau pada awal kelahiran bayi tersebut. ${ }^{9}$

\section{DAFTAR PUSTAKA}

1. Pierson DJ. Pathophysiology and clinical effects of chronic hypoxia. respiratory care. 2000;45 (1): p. 39-46.

2. Marcdante KJ, Kliegman RM, Jenson HB, Behrman RE. Nelson Essentials of Pediatrics. 6th ed. In: Ikatan Dokter Anak Indonesia, translator. Indonesian: Saunders Elsevier; 2014. p. 159-64, 764 .

3. Guyton AC, Hall JE. Textbook of medical physiology. 11th ed. In: Rachman LY, Hartanto H, Novrianti A, Wulandari $\mathrm{N}$, editors. Indonesian: Elservier; 2008. p. 495-578, 1096106.

4. Moller JH, Hoffman JI, Benson DW, Vanhare GF, Wren C. Pediatric cardiovascular medicine. 2nd ed. United Kingdom: Willey-Blackwell; 2012. p. 43-4, 184-7, 254-9.

5. Park MK. Park's pediatric cardiology for practitioners. 6th ed. United States:
Saunders Elsevier; 2014. p. 100-40, 151-2, 207-8.

6. Dorland WAN. Dorland's Illustrated Medical Dictionary. 11th ed. In: Mahode AA, dkk, editors. Indonesian: Elsirvier; 2007. p. 1440, 1576-7, 1946.

7. Dawson JA, Kamlin COF, Vento M, Wong C, Cole TJ, Susan M, et al. Defining the reference range for oxygen saturation for infants after birth. Pediatrics. 2010;125(6): 13415.

8. Sucheta T, Soumya T, Nangia S, Saili A. Oxygen saturation profile in healthy term neonates in the immediate post natal period. Int $\mathrm{J}$ Clin Pediatr. 2013;2(1): 19-22.

9. Hoffman JIE. It is time for routine neonatal screening by pulse oximetry. Neonatology. 2010;99: 1-9.

10.Walderman A. Target ranges of oxygen saturation in extremely preterm infants. N Eng J Med. 2010;362(21): 1959-69.

11.Nuntnarumit $P, \quad$ Rojnueangnit $K$, Tangnoo A. Oxygen saturation trends in preterm infants during the first 15 min after birth. Journal of Perinatology. 2009;30: 399-402.

12.Stenson BJ. Oxygen saturation and outcomes in preterm infants. New England Journal of Medicine. 2013;368(22): 2094-103.

13.Jegatheesan $P$, Song $D$, Angell $C$, Devarajan K, Govindaswami B. Oxygen Saturation nomogram in newborns screened for critical congenital heart disease. Pediatrics. 2013;131(6): 1803-9.

14.Tautz J, Merkel C, Loersch F, Egen O, Hagele $F$, Schalble $T$, et al. Implication of pulse oxymetry screening for detection of congenital heart defects. Klin Padiatr. 2010;222: 291-5.

15.Mills BA, Davis PG, Donath SM, Clucas LM, Doyle LW. Improving complicance with pulse oxymetry alarm limits for very preterm infants. Journal of Paediatrics and child Health. 2009;46: 255-8.

16.DeMauro SB, Douglas E, Karp K, Schmidt B, Patel J, Kronberger A, et al. Improving delivery room 
Jurnal e-Clinic (eCl), Volume 3, Nomor 1, Januari-April 2015

management for very preterm infants. Pediatrics. 2013;132(4): 1018-24.

17.Rabi Y, Singhal N, Aguirre AN. Room-air versus oxygen administration for resucitation of preterm infants. Pediatrics. 2011;128(2): 374-81.
18.Kapadia VS, Chalak LF, Sparks JE, Allen JR, Savani RC, Wyckoff MH. Resusitation of preterm neonates with limited versus high oxygen strategy. Pediatrics. 2013;132(6): 1488-95. 